\title{
Some Glimpses of the American-Armenian Press Published in English in the 1990s
}

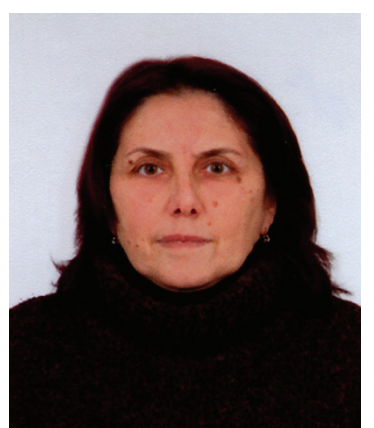

Marina Chalyan

The problem of the American-Armenian press

1 published in English has not yet been thoroughly investigated in spite of its considerable practical importance. Nowadays, there are more than 15 Armenian newspapers published in English in the USA (Hay Spyurq hanragitaran 2003: 76-85).

Out of the great number of Diasporan newspapers three most interesting and reputable publications have been selected for this research and, as our investigation shows, the choice seems to be justified.

It should be mentioned that at present the Armenian press in Diaspora is facing difficulties. As some leaders of political parties state, the majority of the Diasporan Armenians are not politicized and are mainly concerned with the problem of survival in the modern world. The younger generation, in particular, cares less about politics and gives preference to the electronic mass media. As a result, there is little demand for regular newspapers, the publication of which drops from year to year. Many of the Armenian newspapers are not able to cover their own expenses and are directly dependant on various charity contributions; they are financed by individuals or some private organizations. So, the editorial staff of many publications is obliged to apply to the owners of different restaurants, laundries, shopping centres and other companies with a request to finance one or the other series of publications, even the publication of certain articles or photo series. This makes the Diasporan media dependent on sponsors, who retain the right to impose their own taste, will and political views on the editorial staff. Thus, obviously, this has a negative impact on the quality of the publications. Sometimes the newspapers contain articles which are not in line with the political focus of the newspaper, which in its turn breaks the balance among the articles of a single issue of the daily or its consecutive series. As a result, the public may be left with the impression that many editorial staffs of newspapers lack a clear and definite position on this or that issue.

The other problem that the Armenian publications face is once again caused by the insufficient financial resources. The editorial staff cannot afford to employ full-time journalists and that is the reason why the staff is mostly comprised of reporters of retirement or pre-retirement age who are either volunteers or just under-paid. The point is that the journalists of the older generation (many of them from the Middle East and even without a relevant education) are deprived of the possibility to find a job with more 
successful newspapers. Whereas, as a rule, the English speaking and highly educated younger generation does not participate in the activities of the mass media, and even if they do get involved, it is only a short-term activity on a contractual basis. This accounts for the poor quality and low circulation rate of the newspaper.

Besides, the Diasporan publications do not receive newspapers from Motherland and do not have their special correspondents in Armenia which sometimes brings about erroneous and vague understanding of the developments in Armenia. At present the Armenian Assembly of America attempts to change the situation. With this goal set before itself, the Assembly has recently set up an information and analysis centre in Yerevan which aims at providing the Diasporan media with accurate information.

The above mentioned clearly indicates that the Armenian press in Diaspora still remains in an inconsolable situation. Only the Armenian Reporter, the Armenian Mirror Spectator and the Asbarez weeklies, chosen as objects for our research, are the rare exceptions. They have relatively stable sources of funding, are published regularly and have their regular readers. These newspapers have survived the late $80 \mathrm{~s}$ and still reflect the diverse strata and political points of view of the American-Armenians. These weeklies differ from other Diasporan publications of the West in one aspect - they come up with analytical publications more often, and the Armenian leit-motif is always presented in a deeper political coverage without overlooking the values of the mankind. Besides, in comparison with other provincial-like Diasporan newspapers that publish materials of local importance only, the aforementioned publications, have, at least during the period under review, always highlighted the developments in Armenia, have covered issues related to the church, language, culture, history, environment of Armenia.

Moreover, the Armenian Reporter, the Armenian Mirror Spectator and the Asbarez weeklies have a number of significant advantages, too. Before the week ends, these publications already have the information and the material verified and filtered. Compared to daily newspapers, they do not touch upon insignificant and trivial events. As a rule, these publications present the analysis of the most interesting and up-to-date news of the past week, which is, of course, very useful for those studying the events of that period. We should hasten to add that the newspapers in question employ more professional and educated journalists who are official employees of leading American newspapers and magazines, and they simply work for the Armenian weeklies on a parttime basis. The materials they prepare are not only interesting, but written in perfect English, as well. The English-speaking American-Armenian of the third or second generation who reads the Armenian news in English, is well-educated and is brought-up on the best traditions of the American press, and thus is very demanding towards the quality of the materials published. Though the readers of these publications are mainly Armenians, very often they may also serve as a source of information for non-Armenian readers. It is known that the US State Department is a subscriber to all the weeklies mentioned. It enables the American politicians and State officials to get introduced to Armenian viewpoints without any distortions. This was particularly important during the years of the liberation of Arstakh [ed. Nagorno Karabakh] when the American English press voiced not only the thoughts and concerns of the Armenian political elite of the 
USA, but also those of the Armenians worldwide. Thus, the editorial staffs of the three weeklies enjoying the highest circulation rate in the US Armenian Diaspora do not spare their efforts to guarantee the highest possible quality.

For example, the Asbarez has a circulation of 8,000 copies, the Armenian Reporter and the Armenian Mirror Spectator - 3,000 copies each. The other newspapers are printed in relatively fewer copies; The Armenian Weekly - 1,800 copies, the Abaka - 1,000 copies, etc. (Armyanskie Gazety Kalifornii Izdayushchiesya na Angliiskom Yazike. National archives f. 326, 1.7, d.236, p. 2-3). Meanwhile, many of them are published regularly, sometimes with rather long intervals, which is also a very important factor.

However, all these publications have one distinct advantage: they are in a better state as compared with other Armenian publications in the USA, due to the fact that they are published in the eastern States of the USA and they have their publishing houses in both the East and the West coasts. In the course of history, the Eastern states (Virginia, New England) became more developed than the Western states. This could not but have its impact on the level of education and the living standards of the population. Therefore, the most well-known American publications are published in the East coast and they stand out from the rest of the publications with the quality materials and agreeable language they present.

It is impossible to identify the newspapers published in the East coast out of the galaxy of all American publications with a naked eye. Among them are the Washington Post, the New York Times, the Chicago Tribute, the Boston Globe, Christian Science Monitor and several others. Many of them, especially the Boston Globe and the Christian Science Monitor, display pro-Armenian approach. Being a newspaper with a Christian-democratic focus, the Christian Science Monitor has always been faithful to the values of the mankind and has treated the eastern Christians, especially Armenians, with the greatest sympathy.

It is natural, that the Armenian journalists work for the newspapers published in the East coast and highlight issues on the happenings in the Caucasus in general and in Armenia, in particular. Cooperation with the giants of the American mass media industry has given the Armenian journalists the opportunity to obtain first-hand accurate and unbiased information. Moreover, many Diasporan publications make use of some parts of the analytical articles from these weeklies. That is why the three Armenian weeklies are reputed as ones that contain the most reliable and impartial information.

\section{References:}

1. (2003) Hay Spyurq Hanragitaran (Armenian Diaspora: Encyclopedia). Yerevan.

2. National Archives f.366, 1.7, d.236, p.2-3.

3. (1988-1998) The Armenian Mirror-Spectator.

4. (1988-1998) The Armenian Reporter.

5. (1988-1998) The Asbarez. 


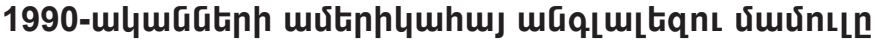

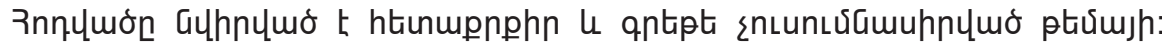

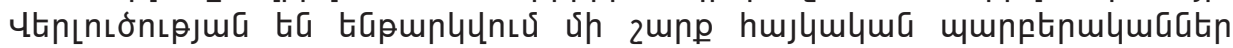

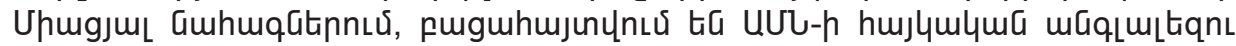

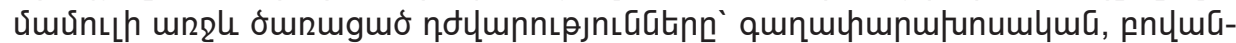

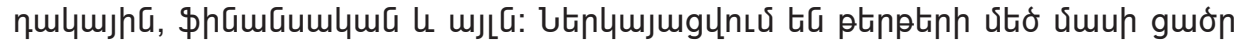

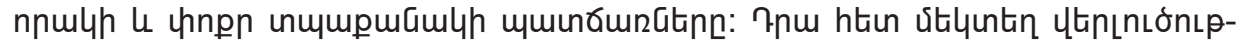

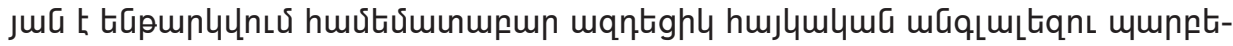
nulquGGtph" "Asbarez", "Armenian Mirror Spectator", "Armenian Reporter", hu-

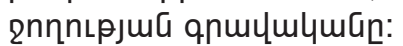

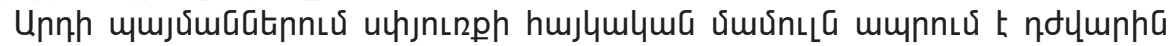

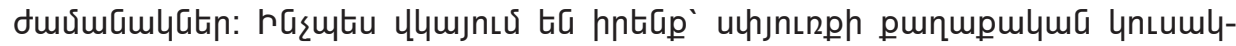

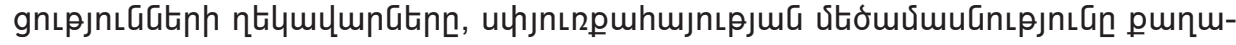

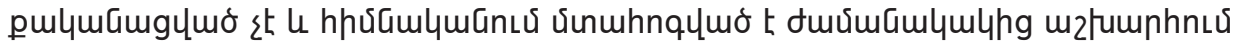

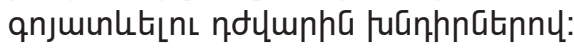

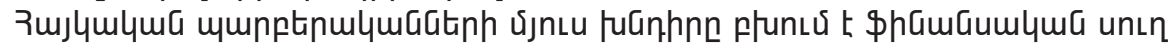

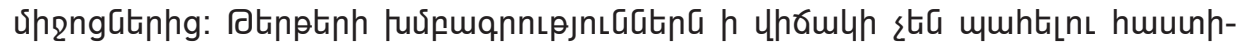

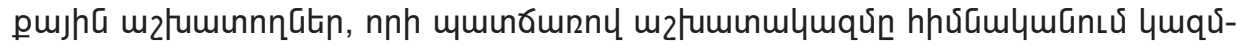

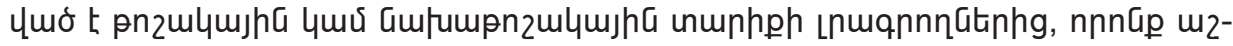

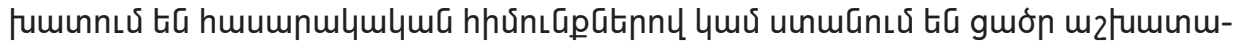
\யună:

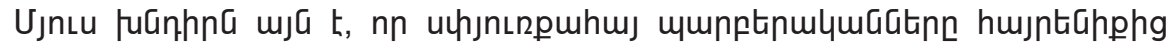

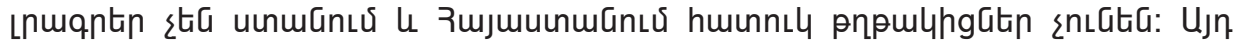

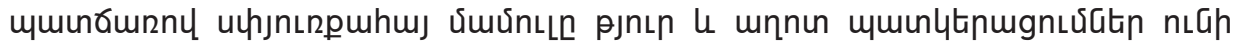

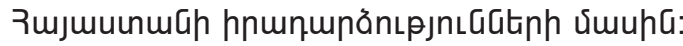

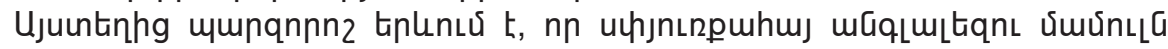

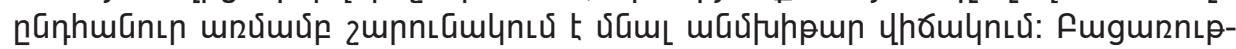

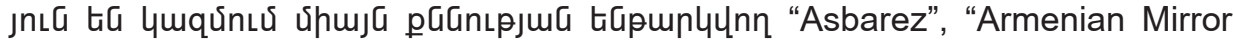
Spectator", "Armenian Reporter" zmpmpmptinptinn, nnnGp nıGiGGuınц \$hGuGG-

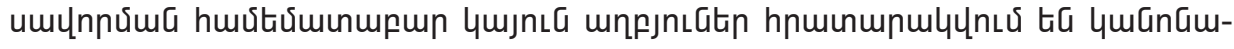

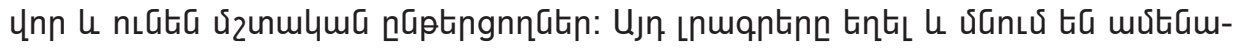

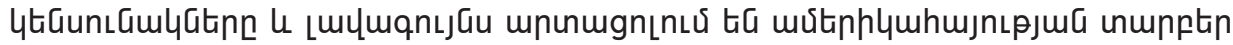

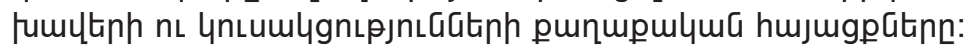

